\title{
Pertunjukan Musik Teatrikal “IBU” Produksi Teater Koma
}

\author{
Arthur S. Nalan ${ }^{1}$ \\ Institut Seni Budaya Indonesia (ISBI) Bandung
}

\begin{abstract}
ABSTRAK
Penelitian ini membahas musik teatrikal bergaya opera dari pertunjukan musik teatrikal Ibu produksi Teater Koma. Teater Koma telah memilih berbagai komunikasi ekpresifnya, di antaranya lakon-lakon asing yang disadur, lakon-lakon Cina, lakon-lakon wayang kreatif, dan lakon-lakon realis ciptaan N. Riantiarno. Setiap produksi lakon-lakon tersebut selalu memakai musik teater yang disesuaikan dengan bentuk dan jenis lakonnya. Musik teater tersebut dapat berupa ilustrasi dan atau pengiring penuh sepanjang pertunjukan berlangsung. Untuk membahas musik teater bergaya opera ini dipilih lakon IBU yang merupakan saduran dari lakon Mother Courage and Her Children karya dramawan Jerman terkenal Bertolt Brecht. Pembahasan meminjam teori sociology of spactacles dan teori komunikasi paradigma naratif, serta teori homofili. Berdasarkan penelitian dapat disimpulkan bahwa pertunjukan Lakon Ibu merupakan teater musikal bergaya opera yang menghadirkan musik teater bersifat kolektif dalam emosi manusia, terutama karakter tokoh. Kontekstualitasnya ketimpangan masyarakat pada masa peperangan, di mana kaum pemodal selalu berada di belakangnya. Lakon IBU juga memiliki dramatik naratif yang menarik bagi penonton, sehingga mampu menciptakan komunikasi yang berdimensi homofili.
\end{abstract}

Kata kunci: teatrikal musikal; dramatik naratif; Teater Koma; Lakon IBU

\begin{abstract}
Theatrical Music Performance "IBU" by Teater Koma. This study aims at exploring the theatrical music in opera style of Teater Koma's production entitled IBU. Teater Koma has chosen its various expressive communications; among others are the adapted foreign plays, Chinese plays, wayang kreatif plays, and realist plays written by N. Riantiarno. Each production of the plays always applies the theatrical music adjusted to its form and type. The theatrical music can be an illustration or full composition for the whole performance. $I B U$ is chosen to discuss the opera style of theatrical music. $I B U$ is an adaptation of "Mother Courage and Her Children", a play written by a German's dramatist, Bertolt Brecht. The analysis applies the theory of sociology of spectacles, of narrative paradigm of communication, and of homophily. The study shows that $I B U$ is a kind of theatrical music in opera style presenting a collective theatrical music in the human emotion, particularly on the characters. The contextuality of the community inequality during the war is also shown in which the investors are always behind its existence. $I B U$ is also a play which has an interesting narrative dramatic for the audience so as it can create a communication with homophily dimension.
\end{abstract}

Keywords: musical theatre; narrative dramatic; Teater Koma; a play of IBU

\section{Pendahuluan}

Pertunjukan musik teatrikal IBU sebagai drama musikal mendudukkan musik sebagai pengatur irama permainan dalam perilaku akting para aktor. Para aktor di dalam membawakan perannya harus memiliki kemampuan khusus dalam menyanyi, karena beberapa dialog dibawakan dengan menyanyi, seperti layaknya dalam sebuah pertunjukan opera. Tairov mengungkapkan bahwa keindahan dan irama musik merupakan prinsip pemersatu untuk gerakan dan ujaran (Posner, 2010: 36). Melalui pendekatan etnomusikologi, tulisan ini selain menelaah dari kajian teater juga

1 Alamat korespondensi: Prodi Teater, Fakultas Seni Pertunjukan, ISBI Bandung, Jl. Buahbatu No 212 Bandung 40265. HP. +628122378061. E-mail: arthur_nalan@rocketmail.com. 
membahas pertunjukan musik teatrikal (Cermatori, 2015: 68). Dalam pertunjukan musik teatrikal IBU menggunakan medium seni ganda atau kolektif karena didukung oleh beberapa cabang seni, antara lain tari, musik, teater, sastra, dan senirupa, seperti halnya Randai yang didukung oleh berbagai cabang seni (Rustiyanti, 2014: 152). Hal ini sangat menarik karena sutradara pertunjukan musik teatrikal IBU yaitu N. Riantiarno sebelumnya pernah menggarap karya Bertolt Brecht, seperti Opera Ikan Asin (saduran dari The Threepenny Opera (1928). Menelusuri proses kreatif penata musik atau seorang komposer pertunjukan musik teatrikal IBU merupakan upaya melakukan pencatatan-pencatatan kreatif karena seringkali terabaikan untuk dibahas. Kajian teater lebih banyak memilih sutradara dan karyanya, dibandingkan seorang penata musik atau seorang komposer. Pencatatan-pencatatan kreatif sangat diperlukan untuk membantu mengungkap alur dramatik yang didukung paradigma naratif musikalnya serta tindakan-tindakan para aktor sesuai perannya dalam membawakan dialog melalui beberapa nyanyian.

Pertunjukan musik teatrikal IBU produksi ke-131 Teater Koma dipertunjukan selama lebih dari dua minggu (1-17 November 2013) yang disutradarai oleh N. Riantiarno dan aktor utama Sari Majid. Penata musiknya dipercayakan kepada Ferosax. Pertunjukan musik teatrikal IBU memberikan peluang besar kepada penata musik untuk menjadikan karya komposisinya sebagai musik teater yang khusus.

Penelitian ini menggunakan metode kualitatif dan dalam pembahasannya meminjam teori sosiologi dari Gay Debord (1994) tentang masyarakat citra (society of the spectacle) yang menekankan bahwa yang dialami sekarang ini telah menjadi representasi. Dorongan kaum pemodal telah menciptakan segalanya sebagai komoditas. Pemanfatan teori ini dapat mengungkapkan upaya sutradara dan komposer sebagai "pemberi cerminan kehidupan " melalui peristiwa dramatik dan musikal tentang kehidupan rakyat kecil dalam bentuk perlawanan melawan penjajah termasuk di dalamnya para pemodal. Para pemodal seringkali berada di belakang penjajah. Representasi tersebut sebagai metode efektif memprovokasi dan membimbing respon emosional yang kuat (Seinen, 2009: 204). Teori paradigma naratif dari Walter Fisher (1984) digunakan sebagai pendekatan terhadap pertunjukan lakon IBU yang memiliki plot epsisodik dan lirik-lirik heroik dan dramatik.

Plot episodik adalah plot yang terbagi dalam adegan-adegan dramatik yang memiliki kesatuan ruang-waktu-peristiwa yang berbeda, di mana tokoh utama (Ibu) selalu berada dalam setiap adegan, meskipun dalam konteks ditampilkan secara langsung dan tidak langsung, tetapi hanya terkisahkan. Kebertahanan pertunjukan selama 17 (tujuh belas) hari mengindikasikan berlangsungnya proses komunikasi berdimensi homofili. Teori homofili dipinjam dari Carley H. Dood (1982). Relasi antara ketiga teori ini menunjukan berlangsungnya paradigma sosiologi komunikasi seni dalam studi kasus pertunjukan musik teatrikal IBU produksi ke-131 Teater Koma.

Saat ini Teater Koma bertahan sudah mencapai selama 40 tahun (1977-2017) merupakan teater modern yang berdomisili di Ibukota Jakarta. Grup ini didirikan oleh N. Riantiarno dan sejumlah orang, telah mempertunjukkan sebanyak 140 lakon. Lakon-lakon yang dimainkan berasal dari Barat, baik asli yang diterjemahkan maupun disadur, lakon Cina, lakon sendiri (realisme dan wayang). Salah satu yang dipilih dalam kajian ini adalah lakon saduran dari Bertolt Brecht (18981956) seorang dramawan Jerman yang telah menghasilkan 44 (empat puluh empat) lakon, sebagaimana tercatat dalam buku Encyclopedia of world drama (1972). Lakon saduran yang dipilih sebagai studi kasus adalah IBU (aslinya Mother Courage and Her Children (1941). Lakon ini menceritakan keberanian seorang ibu bersama anak-anaknya bertahan hidup dan larut dalam perjuangan melawan keangkaramurkaan perang melalui cara-caranya yang dipilih. Lakon ini merupakan drama musikal yang penuh lirik-lirik heroik dan peristiwa dramatik.

\section{Teater Musikal Bergaya Opera Teater Koma}

Apa itu opera? Sebagaimana dinyatakan oleh Anndiva Mandley dan Carol Williams (2014) 
bahwa opera adalah bentuk seni total yang menggabungkan beberapa media ekspresif seperti musik, nyanyi, drama, puisi, seni (pemanggungan), dan terkadang tari. Kombinasi kompleks ini membuat sebuah pertunjukan opera menjadi istimewa, dimana seluruh kegemaran manusia menyatu. Teater Koma sebagian besar lakonnya (saduran maupun asli) merupakan teater musikal bergaya opera.

"Mengenai bentuk Teater Koma? Nyanyi, musik, tari adalah konsekuensi dari pilihan bentuk. Hampir semua jenis Tetaer Rakyat dan Teater Tradisi di Indonesia menggunakan bentuk ramuan seperti itu yang menjadi kesatuan utuh pada pementasannya. Jadi bukan hanya milik Broadway saja. Teater Koma adalah Teater Rakyat Urban. Tentu saja bentuknya kurang lebih serupa dengan Teater Rakyat yang lainnya” (Riantiarno, 2017: 36).

Lakon-lakon teater musikal bergaya opera yang disadur maupun ditulis oleh N. Riantiarno umumnya terdiri atas tiga bagian utama Opera, yakni libreto (naskah sebuah opera), nyanyian (teks emosional dan kuat yang dinyanyikan para aktor), musik (ditujukan ke hati penonton), interpretasi visual pemanggungan dari karya artistik (Mandley dan William, 2014). Lakon yang disadur maupun ditulis N.Riantiarno lebih memilih kebebasan ekspresi di lapangan, artinya sebuah lakon dikenali, dipahami dan dihayati para aktor pada saat latihan sampai pertunjukan. Terdapatnya penyesuaian lirik dan musik merupakan suatu proses kreatif yang biasa dilakukan. Seperti halnya dalam berkarya seni drama, terdapat masalah formasi dari cerita hasil karya sastra menjadi lakon seni pertunjukan drama. Di dalam masalah formasi peristiwa lakon sebagai bagian dari masalah penyutradaraan di samping pemeranan, juga terdapat masalah tata artistik yang di dalamnya termasuk tata pentas (Antono, 2013: 172).

Bagaimana dengan lakon pertunjukan musik teatrikal IBU? Dalam sebuah produksi teater musikal bergaya opera ini memiliki daya tarik tersendiri karena menggabungkan tiga generasi anggota Teater Koma. Selain itu penata musik dipercayakan kepada Ferosax, seorang komposer muda yang mampu menghidupkan suasana dramatik dari setiap episode lakon. Pada manusia, emosi dari musik memiliki peran komunikatif yang penting sehingga konten emosional dari musisi terlihat secara audio visualnya (Petrini, Crabbe, Sheridan, \& Pollick, 2011: 1). Plot episodik yang dibuat Bertolt Brecht serta disadur oleh N. Riantiarno dengan cara mengubah (makeover) nama, adegan, dan nyanyian, yang disesuaikan dengan tingkat apresiasi dan pengalaman estetik penonton. Salah satu yang menonjol adalah nyanyian yang melayani gagasan dramatik sehingga penggunaan chorus dan ensambel untuk menekankan sifat kolektif emosi manusia, terutama karakter tokoh menjadi menonjol.

Teater musikal gaya opera Teater Koma ini merupakan tradisi baru yang bertolak dari opera Barat, baik Opera Seria (Opera serius) maupun Opera Buffa (Opera komik/gembira). Kedua bentuk opera ini dijadikan sumber penciptaan tradisi baru gaya opera Teater Koma. Tradisi yang berbeda dapat dikembangkan di negara yang berbeda, termasuk yang dikembangkan oleh Teater Koma. Opera sekarang lebih beragam dari sebelumnya, di mana pemanggungan dan setting menjadi elemen utama, juga tema-tema operatik kontemporer baru. Karyakarya besar diinterpretasi ulang dan tetap berhasil (Meyer, 2008: 2-3; Mandley dan William, 2014; Baranello, 2016: 363)

\section{Pertunjukan Teater Musikal IBU Produksi Teater Koma Ke-131}

Pertunjukan musik teatrikal IBU merupakan saduran dari Mother Courage and Her Children atau Mutter Courage und ihre Kinder karya dramawan terkenal Jerman, Bertolt Brecht (1941). IBU menceritakan manusia menghadapi hidup dalam suasana perang. Persoalan manusia hidup selalu menarik bagi seorang penulis lakon. Meskipun berasal dari lakon asing yang bersetting perang abad ke-17, ketika manusia menguasai manusia, orang menguasai orang, orang menguasai daerah lain, dapat dipastikan memiliki relasi kuat dengan kekuasaan politik dan ekonomi yang berdampak sosial dimana dalam setiap perang, kaum pemodal turut serta di belakang perang tersebut. 
Pertunjukan musik teatrikal lakon IBU telah diterjemahkan dan disadur oleh N. Riantiarno sejak tahun 1987. Saduran dilakukan untuk mendekatkan lakon yang berasal dari konteks budaya asing (Jerman) ke dalam konteks budaya lokal (Indonesia) salah satunya dengan namanama tokoh yang disederhanakan supaya mudah diingat (misalnya tokoh Anna Fierling menjadi Anna Pirling yang dijuluki Ibu Brani, Eilif menjadi Elip, Chaterine menjadi Katrin, Chaplain menjadi Kaplan, dan Yvete Pottier menjadi Ipit). Adegan dan nyanyian disesuaikan dengan tafsir penyadurnya. Pertunjukan musik teatrikal IBU sejak lama telah menjadi obsesi N. Riantiarno, namun baru tahun 2013 berhasil dipertunjukkan.

Pertunjukan musik teatrikal IBU berkisah tentang sosok Anna Pirling yang dijuluki Ibu Brani, memiliki tiga anak (Elip, Katrin, Kaplan) di dalam suasana perang. Ia melihat peluang bisnis untuk bertahan hidup dalam kondisi peperangan tersebut. Namun pandangannya berubah ketika ketiga anaknya terlibat ke dalam peperangan. Ibu Brani mampu bertahan dan melawan dengan caranya, $\mathrm{N}$. Riantiarno tidak menyajikan "rasa putus asa" dari tokoh utama ini tetapi mengubahnya menjadi "rasa optimis" sebab Ibu Brani memiliki anggapan bahwa perang akan datang silih berganti. Pertunjukan musik teatrikal IBU merupakan sebuah tragedi sosial, sebagaimana estetika Brecht sebagaimana dikemukakan Suryajaya berikut:

"Konsepsi Brecht tentang seni cenderung bersifat "serebral". Keseluruhan karya dan gagasannya diarahkan untuk melawan pakem estetika pasca-Romantik yang amat menekankan perasaan. Bagi Brecht, seni adalah soal pengetahuan yang pada akhirnya berujung pada tindakaan, bukan soal pembangkitan perasaan privat-subjektif. Karena itu dalam estetika Brechtian, peristiwa artistik adalah sekaligus juga peristiwa epistemik dan praktis. Dengan menyaksikan karya seni, pemirsa jadi bertanya-tanya dan merumuskan sudut pandang baru dalam memandang kenyataan aktual-kesadaran baru yang didapatnya dan interogasi atas kenyataan inilah yang mendorongnya untuk mengambil tindakan terhadap kenyataan” (Suryajaya, 2016: 612-613).
N. Rinatirano memahami benar konsep estetika Brechtian ini, karenanya ia menawarkan sebuah pertunjukan yang mengajak lebih dekat penonton untuk "dibawa" oleh nasib Ibu Brani dengan ketiga anaknya. Peristiwa dramatik melalui plot episodik menuntut sutradara untuk menyajikan penataan artistik seperti tata pentas, tata rias-busana, tata lampu, dan tata musik. Pertunjukan musik teatrikal IBU penataan musiknya disajikan bergaya opera, karena itu lebih menonjol rasa musikalnya. N. Riantiarno sebagai sutradara dan Ferosax sebagai penata musik berhasil bekerjasama melalui "tafsirtafsir kreatif." Mereka mampu meramu adeganadegan episodik yang dramatik menjadi "tontonan sekaligus tuntunan" di mana pesan-pesan kemanusiaan dibalut dalam musikalitas yang memikat penonton. Para aktor diberi porsi untuk "membawakan" prolog dan dialog serta epilog dengan cara "menyanyikannya" layaknya sebuah opera. Berikut catatan pengalaman Ferosax sebagai penata musik pertunjukan musik teatrikal lakon IBU:

“Dalam "Opera Ikan Asin” proses kreatif hampir nihil, karena sifatnya hanya menyajikan musik asli dari Kurt Weill dengan beberapa penyesuaian. Yang berbeda pada produksi tahun 2017 tersebut hanyalah disajikannya lagu penutup sesuai aslinya. Pada produksi "Opera Ikan Asin" sebelumnya tidak disajikan lagu penutup dengan lengkap, hanya beberapa bagian saja. Dalam "Ibu", semua komposisi adalah baru, tetapi tetap mengacu pada kebutuhan naskah \& musik asli "Mother of Courage". Proses kreatif lebih mengarah kepada pencarian referensi, lalu komposisi baru dibuat dengan lirik yang tercantum dalam naskah, tanpa mengubah ide musikal dasar dari komposisi musik aslinya (mood, tempo, gaya musik, \& detail lainnya relatif serupa)" (wawancara dengan Ferosax, 16 November 2017).

Pengalaman penata musik tersebut menarik untuk dielaborasi terutama tahapan proses kreatifnya. Musisi yang satu dengan musisi lainnya dapat memainkan skor musik yang sama dengan menggunakan strategi ekspresi dan muatan emosional yang berbeda-beda sehingga memunculkan pengkodean dan persepsi ekspresi 
emosi yang berbeda pula (Giordano, Egermann, \& Bresin, 2014: 2). Penata musik melakukan studi referensi yang berhubungan dengan Brecht dalam konteks lakon-lakon musikalnya dimana Brecht seringkali menulis dalam bentuk teater musikal yang juga memberikan "kemampuan" akting bagi pemerannya yaitu mampu bernyanyi. Selain itu berdasarkan "konsep musikal" sutradara N. Riantirano yang sejak awal berkembangnya teater Koma berkeinginan untuk mendudukkan pentingnya teater musikal. Berikut catatan yang dikemukakan N. Riantiarno atas pilihannya:

"Dalam setiap naskah saya, selalu ada lirik. Bisa diucapkan begitu saja, seperti sebuah dialog yang dipuisikan secara ritmis, tetapi bisa juga dinyanyikan, dirangkum menjadi lagu dan dimusiki. Saya cenderung menulis naskah-naskah yang punya kemungkinan dinyanyikan. Nyanyian, bisa sebuah rangkaian melodi yang sendu atau manis. Meski bisa juga merupakan kumpulan nada-nada yang sumbang, atau menggebrak dengan garang" (Riantiarno, 2017: 7).

Catatan sutradara tersebut memberi petunjuk bahwa teater musikal bergaya opera adalah sebuah pilihan yang telah disadari benar oleh Teater Koma sebagai identitas yang akhirnya eksis di masyarakat pecintanya. Namun proses menghadirkan sebuah teater musikal bergaya opera tidaklah semudah yang dibayangkan. Teater Koma tidak memiliki aktoraktor yang memiliki bakat menyanyi, sementara untuk kebutuhan teater musikal dibutuhkan bakat tersebut. Teater Koma menjalankan proses "gagal dan mencoba" (trial and error) yang berarti sebuah proses kreatif dimana aktor yang mendapat peran diharuskan belajar menyanyi, sementara dia tidak bisa bernyanyi. Salah satu catatan Sutradara kembali dikemukakan Riantiarno berikut:

"Selama satu bulan, latihan berjalan sendat dan selalu mandek pada adegan itu. Adegan sering dia wujudkan dengan air mata yang berderai-derai. Saya bilang, bukan air mata yang diinginkan adegan, tapi keharuan. Sebuah permainan dalam, yang getir. Dari kegetiran, penonton bisa tertawa sambil menangis. Itulah kehidupan kita, konyol dan getir. Mungkin permintaan saya keterlaluan, karena itu dia tetap tidak mampu melakukan apa yang saya minta. Akhirnya saya mengambil sebuah "alternatif" yang agak riskan. Saya bebaskan dia dari semua ikatan; musik, not, ritme, ketukan, nada, dan nyanyian. Dia boleh mengucapkan dialognya dengan bunyi yang dia rasa benar. Saya berharap, melodi atau "nyanyian" akan tercipta dengan sendirinya. Ternyata, hasilnya di luar dugaan. Langkah "alternatif" itu menemukan jalannya. Dia mampu bergerak dan lebih bebas. Tak ada lagi ikatan. Tubuhnya meliuk-liuk lentur dan sumbangnya "nyanyian" tak terasa lagi. Kesedihan, yang "dinyanyikan", sangat meyakinkan. Adegan kematian itu sudah menjadi miliknya, bukan lagi milik naskah dan sutradara” (Riantiarno, 2017: 8).

Selalu ada jalan keluar dalam sebuah produksi teater, sebagaimana dicontohkan oleh N. Riantiarno dalam menangani seorang aktor yang tidak bisa menyanyi. Kemampuan untuk mengikutsertakan musik dengan berbagai cara yang canggih merupakan kemampuan manusia yang unik dan universal (Müllensiefen, Gingras, Musil, \& Stewart, 2014: 1). Pengalaman tersebut menjadi "jalan keluar" baginya untuk melakukan proses kreatif bersama para aktor Teater Koma yang tidak memiliki bakat menyanyi. Caranya dengan metode "kebebasan" berekspresi yang penting adegannya hidup dan pesannya sampai. Sebenarnya sutradara telah menjalankan permainan bebas (free play) dan doktrin kemauan bebas (free will doctrine) (Chaplin, 1989:199). Permainan bebas adalah bentuk permainan yang tidak diatur oleh seorang pengawas (dalam hal ini sutradara), sedangkan doktrin kemauan bebas bahwa tingkah laku itu pada akhirnya diatur oleh kemauan, tanpa menghiraukan pengaruh eksternal. Maka akhirnya para aktor Teater Koma mampu berakting sambil bernyanyi.

Peralihan para aktor berakting sambil bernyanyi dalam pertunjukan musik teatrikal IBU menjadi kajian penelitian, perlakuan sutradara tidak jauh berbeda dengan penggarapan sebelumnya dan sesudahnya di mana Teater Koma telah menggarap lakon-lakon yang pernah digarap dalam kategori teater musikal bergaya opera. Teater musikal bergaya 
opera merupakan salah satu genre dari teater yang dominan diiringi musik. Sebagian besar para aktor, selain berakting, diharuskan mampu membawakan lirik yang dinyanyikan, terutama pada bagian tertentu (Rogers, 2014: 198). Termasuk di dalamnya prolog dan epilog. Tercatat teater musikal Teater Koma yang bergaya opera, antara lain: Opera Salah Kaprah (1984), Opera Kecoa (1985), Opera Julini (1986), Opera Primadona (1988), Opera Ular Putih (1994), Opera Sembelit (1998), Opera Ikan Asin (1999), dan Opera Salon (2001). Lakonlakon tersebut umumnya dimainkan tidak satu kali dan rata-rata mampu bertahan selama 17 (tujuh belas) hari pertunjukan. Sementara pertunjukan 'IBU di dalam penggarapan komposisi musiknya telah mendapatkan "sentuhan" baru, sebagaimana dinyatakan Ferosax (2017):

"IBU adalah yang paling menantang, di mana sutradara menginginkan komposisi baru dengan acuan komposisi aslinya. Selain itu dijalaninya latihan-latihan bagi para aktor supaya tidak buta nada. Memang waktu dan porsi latihan menentukan juga kemauan para aktor yang bersangkutan. Lakon IBU yang episodik banyak membantu prioritas penggarapan.”

Plot episodik menjadi peluang besar dikaji secara teori komunikasi paradigma naratif Fisher sebagai berikut:

"Narasi merupakan akar komunikasi dalam waktu dan ruang. Narasi meliputi setiap aspek dalam hidup kita dan kehidupan lain dalam karakter, motif, tindakan. Narasi sesungguhnya selalu berhubungan dengan setiap tindakan verbal dan non verbal meminta setiap orang untuk percaya atau sebuah tindakan pada sebuah jalan yang pasti. Ketika sebuah pesan nampak abstrak-tanpa perumpamaan- sebab itu narasi mendudukan seorang pembicara menjalankan cerita untuk sebuah awalan, tengah dan akhir, serta hal ini mengundang pendengar untuk menafsirkan makna dan menaksir nilai bagi kehidupannya sendiri." (Fisher, 2006: 341).

Paradigma naratif yang tercermin dari kutipan tersebut mengarahkan kajian untuk mampu melakukan penjelasan-penjelasan bahwa lakon dalam pertunjukan musik teatrikal IBU memenuhi apa yang dinyatakan Fisher sebagai narasi. Kehidupan Ibu Brani atau Anna Pirling dengan tiga anaknya dalam situasi perang yang penuh kepentingan, baik kekuasaan berkuasa maupun kekuasaan ekonomi oleh kaum pemodal, di mana mereka sering memanfaatkan perang sebagai lahan bisnis, seperti bisnis senjata dan bahan makanan. Karakter Ibu Brani digambarkan memiliki caracara strategis untuk mempertahankan hidup. Lakon aslinya memperlihatkan Ibu Brani akhirnya bunuh diri dengan menggantung diri. Namun di tangan N. Riantiarno sebagai sutradara berakhir berbeda, seperti dicatatkan Cindy Audila (2013):

"Pementasan ini menyajikan persoalan dan membangkitkan daya kritis yang kuat. Penonton seolah-olah diajak untuk mencari jalan keluarnya secara bersamasama. Itulah sebabnya mengapa pada akhir pementasan, Ibu Brani tidak menggantung diri dari gerobaknya dengan tali yang sudah mengikatnya. Penonton dibuat penasaran dengan aksi terakhir Ibu Brani yang justru tidak diakhiri dengan menggantung dirinya. N. Riantiarno tidak bermaksud sekadar menghibur penontonnya, tapi juga ingin membuat mereka berpikir. Ia menyuguhkan sebuah pertunjukan drama yang latar dan kondisinya jauh dengan era modern saat ini, namun masih bisa dihubungkan dengan kondisi yang sebagian sedang terjadi seperti, korupsi, penyuapan, pelacuran yang dimaklumi, penggerogotan harta dengan cinta palsu, ketidaksetiaan masyarakat terhadap satu pihak demi uang, merampas ternak petani, dan degradasi moral lainnya”.

Pada sisi yang lain terdapat catatan sutradara yang dipetik dari buku acara pertunjukan musik teatrikal IBU (2013):

"November 2013, kami memainkan karya Bertolt Brecht, Mother Courage and Her Children. Judulnya saya ganti, IBU. Jadi siapakah 'IBU' Indonesi yang sekarang ini ? Naskah ini sudah diterjemahkan Mei 1987. Rasanya, memang tahun 2013 adalah tahun yang sangat penting sehingga IBU, 
bagaimanapun harus dipentaskan. Naskah itu saya revisi lagi. Berdasar hasil revisi ulang itulah naskah ini kemudian dipentaskan. Tidak ada yang berubah, tapi saya ingin melihat naskah ini dipentaskan dengan mencampurkan Jerman dan Indonesia, atau sesuatu yang bersifat Nusantara. Maka, di pentas akan nampak padi, tebu, terong, bawang, cabe, ketela, ubi kayu dan palawija. Eropa, moralitas kekuasaan yang kacau akibat kapitalistik terhadap ekonomi dan kebudayaaan".

Menggarisbawahi kalimat terakhir yakni "Moralitas kekuasaan yang kacau akibat kapitalistik terhadap ekonomi dan kebudayaan" dalam konteks masyarakat citra dari G. Debord (1994) bahwa dalam masyarakat mutahir, di mana dunia sosial dan natural dihadirkan sebagai citra-citra pertunjukan. Citra yang dimiliki oleh seorang aktor (penari) pada dasarnya harus memiliki ketrampilan gerak (akting), memiliki kepekaan irama, percaya diri, dan menjiwai akting yang diperankan (Rustiyanti, 2013: 159). Rustiyanti menyatakan bahwa kapitalisme (capitalism) telah menjadikan kehidupan sehari-hari dan menjadikan segalanya sebagai komoditas (Abercrombie, 2010: 530). Kembali N. Riantiarno sebagai sutradara mencatatkan di dalam buku acara pertunjukan musik teatrikal IBU (2013):

"Kata Bertolt Brecht, 'Dalam perang, yang kalah dan yang menang hanya akan menerima kerugian. Semuanya kalah.' Kelak, mungkin hanya urusan ekonomi dan juga politik yang menerima keuntungan. Kadang, kebudayaan menjadi tidak penting lagi, bahkan dihapuskan, ditiadakan. memang perang sering melakukan halhal seperti itu. Kemudian siapakah IBU? N. Riantiarno sebagai sutradara mencatatkannya: itu pertanyaan yang paling pokok. Apakah IBU mereka adalah 'orang-orang pemerintah' atau 'penguasa'? Siapa sesungguhnya mengurusi rakyat sekarang ini? Partai politik? Mereka yang 'menguasai' kita, atau 'modal asing'? Atau mereka yang seharusnya duduk sebagai orang-orang di pemerintahan? Demi Allah, harus ada yang bisa menjawabnya. Ini pertanyaan yang sungguh sangat serius"
Sutradara mengarisbawahi tentang perang dan segala impilikasinya, bahwa dalam perang semuanya kalah. Sebenarnya siapakah yang diuntungkan? Simak lirik-lirik lagu dalam IBU yang diaransemen oleh Ferosax. Lirik-lirik dikutip dari buku acara pertunjukan musik teatrikal IBU (2013). Lirik-lirik ini dianalisis dengan meminjam teori paradigma naratif Fisher sebagai berikut:

"Paradigma naratif memiliki lima asumsi dalam konteks komunikasi: (1) orang-orang adalah juru kisah esensial; (2) Kita pembuat keputusan dalam berbagai alasan yang baik, melalui berbagai variasi situasi komunikasi, media, dan genre (filosofis, teknis, retorik, atau artistik); (3) Sejarah, biografi, budaya, dan penentuan karakter tentang apa yang menjadi pertimbangan alasan-alasan yang baik; (4) rasionalitas naratif adalah ketekunan melalui pertalian dan kesetiaan terhadap lakon yang diceritakan; (5) Dunia adalah sebuah kumpulan cerita dari yang kita pilih, dan juga selalu dikreasikan, tentang kehidupan kita (Fisher, 2006: 343).

\section{Orang-Orang adalah Juru Kisah yang Esensial}

Bertolt Brecht seorang dramawan Jerman yang terkenal telah menciptakan lakon Mother Courage and Her Children (1941), N. Riantiarno menyadurnya tahun 1987 dan merevisinya tahun 2013. Berikut sinopsisnya:

"Kisah Anna Pirling dan tiga anaknya (Elip, Fejos, dan Katrin), di mana mereka berempat menjadi saksi membusuknya kemanusiaan. Anna Pirling atau Ibu Brani tidak peduli. Bagi dia, tidak masalah pihak mana yang membeli dagangannya, asalkan punya uang. Siapa saja boleh jadi pembeli. Prinsip ibu Brani, dia tidak mau terlibat tapi harus memperoleh untung dari peperangan. Sayang, malang tak dapat ditolak. Elip dan Fejos direkrut jadi tentara. Ibu Brani kini hanya memiliki Katrin. Ibu berjanji akan mencarikan suami bagi Katrin saat perdamaian tiba. Dia tidak mau Katrin bernasib seperti Ipit Poter, wanita jalang langganan warung Ibu Brani. Tak lama setelah itu, dua pria pun 
memasuki kehidupan sang Ibu. Keduanya mengagumi ibu Brani. Ada Kaplan, pendeta dari Resimen Matahari Hitam, yang menyamar jadi pelayan warung kereta ibu Brani ketika Matahari Putih menyerang. Ada Domba Si Koki alias Piter Si Pipa, tukang masak seorang jenderal Matahari Hitam, lelaki mata keranjang yang sudah menggombali banyak wanita. Keduanya berusaha mendapatkan hati sang Ibu. Bagaimana nasib anak-anaknya yang direkrut tentara, Elip dan Fejos? Apakah Katrin akan mendapatkan suami? Siapa di antara Kaplan dan Koki yang akan berhasil membuat ibu Brani berpaling? Di akhir peperangan, apakah keuntungan yang didapat ibu Brani?”

Lakon pertunjukan music teatrikal IBU dalam konteks komunikasi dihubungkan dengan asumsi pertama dalam paradigma naratif yakni menyoroti bahwa 'orang-orang adalah juru kisah yang esensial' diperlihatkan oleh Bertolt Brecht melalui tokoh Anna Pirling alias Ibu Brani mengisahkan dirinya dan anak-anaknya. Judul lirik ini setelah disadur N. Riantiarno menjadi Tidurlah anaku sayang.

Tidur, tidurlah anakku sayang

Tiada lagi yang perlu kau risaukan

Anak-anak tetangga meratap

Tapi anakku bahagia

Anak-anak tetangga berbaju rombengan

Bajumu sutera bikinan para malaikat

Mereka semua kelaparan

Tapi kau makan roti coklat

Kalaupun basi, ada roti lain

Tidur, tidurlah anakku sayang

Tiada lagi yang perlu kau risaukan

Satu anakku mati di tanah seberang

Satu lagi entah di mana sekarang

Lirik Tidurlah anakku sayang, kalau ditinjau dari paradigma naratif tentu menunjukkan kehadiran "juru kisah” dan ada "yang dikisahkan”. Secara esensial menggambarkan seorang ibu ketika kehilangan anak-anaknya. Peristiwa tersebut merupakan tragedi kemanusiaan karena diakibatkan oleh perang. Perang selalu menciptakan tragedi dan menyisakan penderitaan yang panjang, terutama warga sipil dan rakyat kecil.

\section{Kita Pembuat Keputusan}

Asumsi kedua dalam komunikasi paradigm naratif bahwa "kita pembuat keputusan" dalam berbagai alasan yang baik, melalui berbagai variasi situasi komunikasi, media, dan genre, baik filosofis, teknis, retorik, atau artistik. Kita dapat menyoroti lirik Nyanyian Atas Nama.

Mereka menyulut api peperangan

Katanya, demi perdamaian dan Tuhan

Mereka menyulut api peperangan

Katanya, atas nama segala mimpi dan keindahan

Tapi coba lihat lebih teliti lagi

Jika gudang gudang istana melimpah ruah

Permata gemerlapan di leher permaisuri

Dan pesta digelar hampir tiap hari

Apa itu kepentingan perang?

Mereka cerdik seperti buaya

Selalu bicara atas nama

Atas nama, atas nama dan atas nama tanyakan, siapa lebih sering lapar menggigil? petinggi itu atau rakyat kecil?

Lirik tersebut dihubungkan dengan asumsi kedua dalam komunikasi paradigma nanaratif menunjukan konteks "kita pembuat keputusan" yang menceritakan "mereka yang selalu mengatakan atas nama", misalnya atas nama perdamaian dan atas nama Tuhan. Namun di balik itu, semua mengakibatkan penderitaan bagi rakyat. Kontradiksi dihadirkan antara "petinggi' dan "rakyat kecil", sebagaimana dituturkan Bertolt Brecht yang disadur N. Riantiarno. Lirik Nyanyian Atas Nama memberi gambaran variasi komunikasi yang mengandung filosofis, teknis, retorik, dan artistik. Keragaman dalam kesatuan kontekstualitas diperlihatkan oleh lirik tersebut.

\section{Sejarah, Biografi, Budaya dan Penentuan Karakter}

Asumsi ketiga dari komunikasi paradigma naratif adalah "sejarah, biografi, budaya, dan penentuan karakter tentang apa yang menjadi pertimbangan alasan-alasan yang baik", menjadi penting diposisikan dalam lakon pertunjukan music teatrikal IBU, sebagaimana tercermin di dalam lirik Kisah Ipit Poter. 
Ketika usiaku dua windu

Musuh menyerbu negriku

Dia menyarungkan pedangnya

Dan menggandengku sambil tertawa

Sesudah parade di bulan Mei

Cahaya rembulan pun memudar

Tentara bergegas memakai seragam

Genderang dipukul saat latihan

Musuh menyerbu dari balik kelam

Tapi kami bercinta sepanjang malam....

Cinta yang begitu

Bagai cakar takdir yang beku

Sahabatku bertanya mengapa

Tapi aku tak pernah tahu jawabannya

Ladang mulai dibasahi embun

Waktu kutahu apa artinya kesedihan

Tentara bergegas memakai seragam

Genderang dipukul saat latihan

Lalu musuh yang juga kekasihku itu

Berjalan lenyap ditelan kabut.. kabut..

Ipit Poter adalah bagian dari sejarah perang tersebut, di mana dia menjadi pelacur "pemuas nafsu" tentara penjajah untuk bertahan hidup. Tokoh tragis ini mengisahkan dirinya dan situasi perang yang dijalaninya.

\section{Rasionalitas Naratif}

Asumsi keempat dalam komunikasi paradigma naratif adalah rasionalitas naratif, yaitu ketekunan melalui pertalian dan kesetiaan terhadap lakon yang diceritakan. Hal ini dapat diperlihatkan melalui lirik Tentara dan Bunga.

Kembang mawar di lindap pepohonan

Mempesona kita karena keindahannya

Cantik berseri bunga-bunga itu

Bikin terang jiwa yang lelah dan ragu

Sesudah guyuran hujan musim panas

Bahagialah mereka yang punya bunga-bunga

Ketika agin dingin membersit lalu

Meniup dari celah-celah belantara

Rumah kami hangat dan nyaman

Karena kami memiliki dinding dan atap

Meski hanya dari anyaman rerumputan

Bahagialah mereka yang punya tempat bernaung

Saat angin dingin yang beku membersit lalu
"Tentara" adalah tokoh komunal yang menjadi bahan pembicaraan dalam setiap peperangan dari dulu sampai sekarang. Tentara di dalam peperangan selalu memiliki dua pilihan, yaitu membunuh atau terbunuh (kill or to kill). Perang menjadi tempat eksistensi mereka. Kalah dan menang menjadi keinginan dan ketakutan mereka. Sementara "bunga" simbolisasi dari kedamaian yang masih menjadi impian rakyat kecil yang dijajah ketika perang terjadi di negerinya.

\section{Dunia adalah Sebuah Kumpulan Cerita}

Asumsi kelima dari komunikasi paradigma naratif adalah "dunia adalah sebuah kumpulan cerita dari yang kita pilih, dan juga selalu dikreasikan, tentang kehidupan kita”. Hal ini dapat diperlihatkan melalui lirik Mars Perang.

Oo, pukulan perang

Bikin bumi makin telanjang

Oo, pukulan perang

Nasib si kalah dan pemenang

Jaya dan terhina ganti berganti

Anugerah dan musibah berganti ganti

Gendewa perang wajib dipentang

Perintah raja pantang ditentang

Akibat perang langit berbau busuk

Tiada ada sabun sabun sanggup mencucinya

Sawah ladang jadi gersang tandus

Tiada bajak sanggup menyuburkannya

Oo, pukulan perang

Bikin bumi makin telanjang

Oo, pukulan perang

Nasib si kalah dan pemenang

Tahun baru datang dan menghilang

Pohon-pohon tumbuh lalu tumbang

Manusia dilahirkan kemudian mati

Tapi kehidupan tak juga berhenti

Bergerak, menembus berjuta kemalangan

Merangkak, tertatih menuju ketidakpastian

Entah sampai kapan. Entah sampai kapan

Oo, pukulan perang

Bikin bumi makin telanjang

Oo, pukulan perang

Nasib si kalah dan pemenang 
Lima asumsi paradigma naratif Fisher menunjukan peranan dan fungsinya sebagai penjelasan bahwa lakon dalam pertunjukan music teatrikal IBU memiliki capaian dramatik naratif. Dramatik naratif pertunjukan musik teatrikal IBU dapat ditelusuri dari lakon epsisodik yang dihadirkan sutradara berdasarkan lakon karya Bertolt Brecht. Pada dasarnya secara universal manusia adalah mahluk bertutur (homonarrans)
(West dan Turner, 2007: 376). Baik Bertolt Brecht maupun N. Riantiarno telah mendudukan dirinya sebagai homo narrans.

\section{Dimensi Homofili Pertunjukan Musik \\ Teatrikal IBU}

Pemahaman umum tentang teater tidak akan berarti tanpa penonton. Pertunjukan teater tanpa

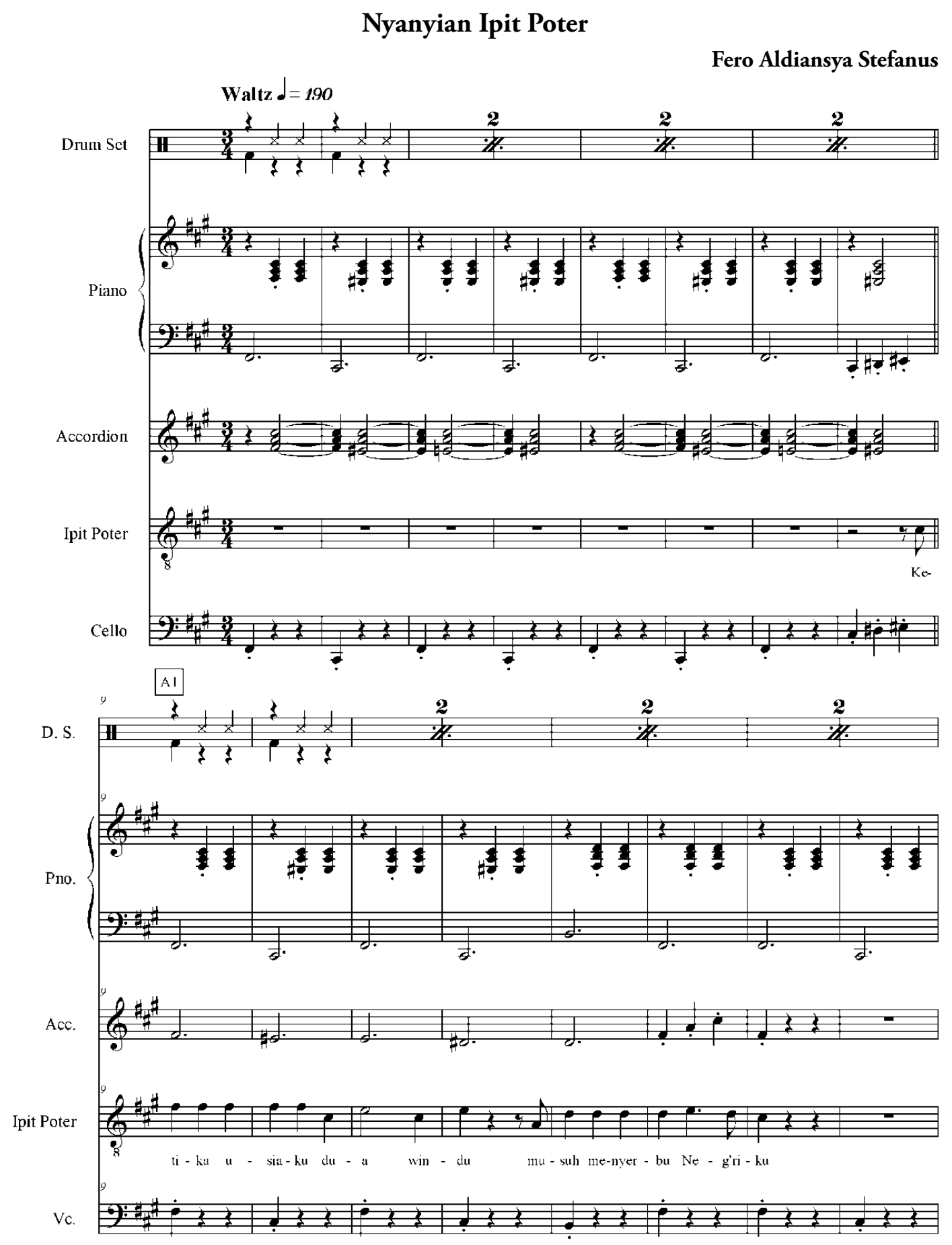

6. October 2013 - Teater Koma "IBU" 
penonton tidak berarti apa-apa karena tidak akan pernah berlangsung komunikasi dua arah, relasi timbal bailk, bahkan interaksi dinamis antara tontonan dan penonton. Penonton, baik individu maupun kelompok membangun relasi timbal balik dengan pertunjukan yang di tontonannya. Beberapa penonton akan merasakan kedekatan dan keakraban dengan semua gaya musikal. Sebagian besar penonton akan mengalami kesenangan dan guncangan untuk menemukan jejak-jejak yang familiar dan eksotis (Sheppard, 2009: 287). Proses membangun relasi timbal balik itu berlangsung karena hadirnya dimensi homofili. Sebagaimana dinyatakan oleh Carley H. Dood dalam Mega

\section{Ibu vs Kapten}

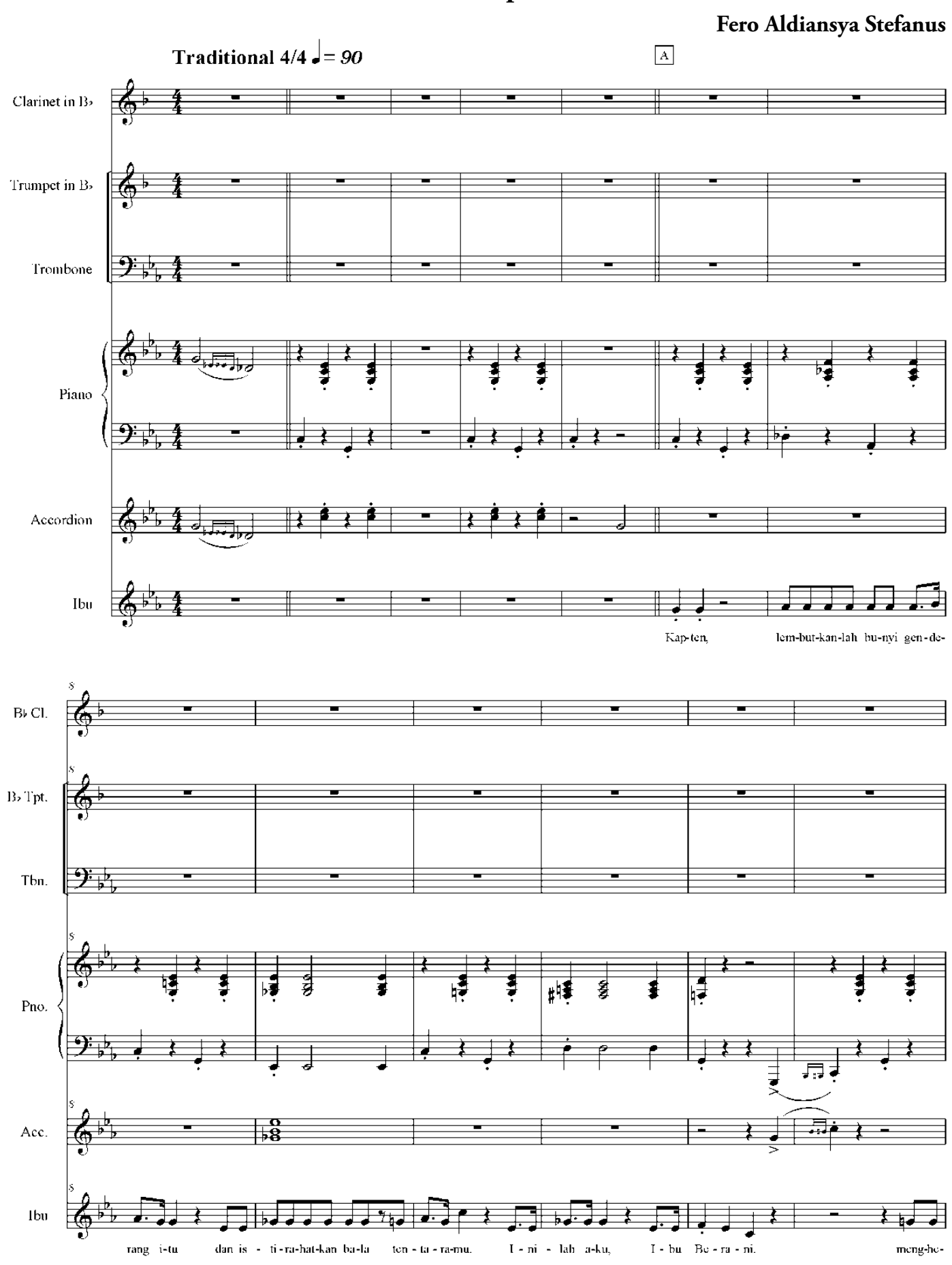


Sufriana (1982: 168-170) tentang klasifikasi dimensi homofili yaitu: (1) Homofili dalam penampilan; (2) Homofili dalam latar belakang; (3) Homofili dalam sikap; (4) Homofili dalam nilai; (5) Homofili dalam kepribadian.

Pertunjukan teater musikal gaya opera IBU dari Teater Koma dilihat dari sudut pandang pelaku komunikasi, yakni tontonan dan penonton. Tontonan dilakukan oleh sekelompok orang-orang kreatif, di mana mereka membawakan sebuah lakon episodik dan dramatik dengan segala kompleksitas artistiknya. Sementara penonton dilakukan oleh individu-individu yang berminat melakukan apresiasi seni dan hiburan yang datang dengan membayar tiket. Meminjam salah satu klasifikasi dimensi homofili dari Dood (1982) yaitu homofili dalam penampilan. Tontonan dan penonton dapat dikatakan sebagai pelaku komunikasi yang memiliki homofili dalam penampilan, di mana berlangsung proses komunikasi estetik dalam homofili. Artinya di antara tontonan dan penonton tercipta derajat persamaan yang saling memahami, dimana para aktor dan aktris membuat percaya (making believe) melalui aktingnya dalam menghidupkan karakter tokoh-tokoh yang dimainkan kepada penonton, bukan sebagai pribadi tetapi sebagai tokoh dramatik yang berkarakter. Sebaliknya para aktor dan aktris berusaha bermain dengan "irama permainan” yang meyakinkan, sehingga penonton menikmati kehidupan dramatik di atas panggung. Pertunjukan musik teatrikal IBU juga memberikan gambaran-gambaran artistik yang menarik secara audiovisual, khususnya dalam komposisi-komposisi musik yang berperan kuat karena musik mampu

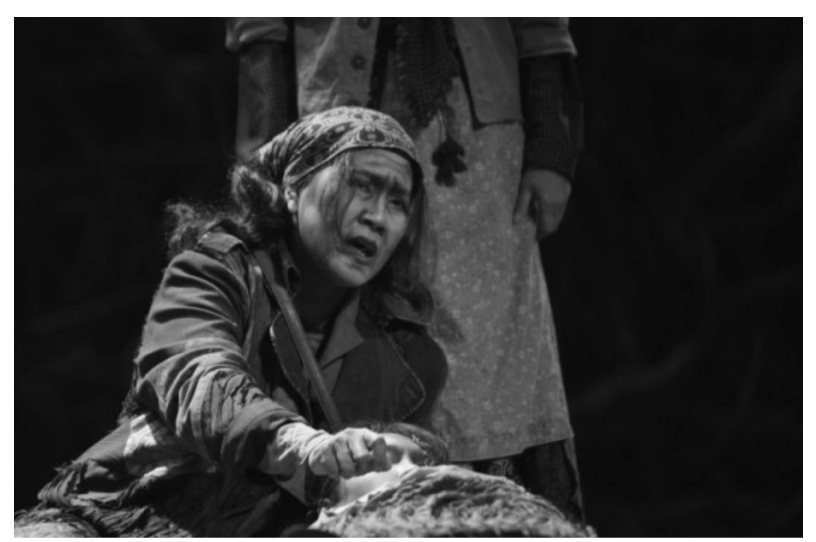

Gambar 1. Pertunjukan music teatrikal Sari Madjid sebagai Anna Pirling atau IBU Brani (https://www. teaterkoma.org/index.php/galeri-foto-koma). menghidupkan suasana-suasana dramatik di dalam setiap adegan. Metafora dimunculkan untuk menyediakan batas usaha manusia yang tertanam dalam peristiwa yang lebih besar (Lütteken, 2009: 233). Selain itu derajat persamaan saling memahami itu dapat dipandang dari kepentingan komunikasi sebagai komunikasi antarbudaya, di mana budaya luar (lakon Bertolt Brecht) yang telah disadur N. Riantiarno menjadi budaya lokal (lakon IBU) disajikan dalam durasi pertunjukan selama 3 (tiga) jam, mampu menciptakan keterpesonaan penonton karena hadirnya lirik-lirik heroik dan dramatik yang dikuatkan oleh kemampuan aktor dan aktris serta dukungan musikalitas yang mampu menghidupkan suasana. Hal tersebut diharapkan mampu memunculkan kesetiaan penonton, untuk melakukan kunjungan berulang, menjadi anggota atau dapat pula secara tidak langsung mengadvokasi kehadiran orang lain dalam pertunjukan opera (Hall, Binney, \& Vieceli, 2016: 142). Pada dasarnya Brecht maupun N.Riantiarno dapat disebut sebagai homo narrans yaitu orang yang mampu menciptakan metafor yang melingkupi humanitas (West dan Turner, 2007: 377).

Hadirnya "pesona” pertunjukan musik teatrikal IBU bagi yang menonton langsung sudah dapat dipastikan, untuk yang tidak menonton langsung tidak akan merasa akrab dengan paparanpaparan lirik yang terdapat dalam lakon IBU. Juga suasana dramatik yang tercipta selama pertunjukan berlangsung. Oleh karena itu peneliti merasa perlu melampirkan contoh partitur musik IBU karya Ferosax dan salah satu foto pertunjukan musik teatrikal IBU.

\section{Penutup}

Penelitian tentang musik teatrikal bergaya opera yaitu IBU produksi Teater Koma merupakan upaya untuk memperlihatkan bahwa di dalam dunia teater modern Indonesia telah muncul bentuk-bentuk baru yang memperkaya khasanah teater Indonesia. Salah satunya adalah pertunjukan music teatrikal IBU yang berhasil diapresiasi selama 17 (tujuh belas) hari. IBU merupakan media komunikasi kreatif dan ekspresif dari sutradara N. Riantiarno serta penata musik Ferosax yang telah 
berusaha keras menghadirkannya sebagai tontonan yang komunikatif.

Kerja kreatif sutradara dan penata musik dalam pertunjukan musik teatrikal IBU telah menunjukan pula bahwa menggarap teater musikal bergaya opera memerlukan upaya-upaya pencarian jalan keluar untuk mencapai komunikasi fomofili antara pelaku komunikasi yaitu tontonan yang dilakukan seluruh aktor dan penata artistik dan penonton yang beragam, namun memiliki tujuan sama mendapatkan apresiasi seni dan hiburan. Hal tersebut sekarang ini telah menjadi "modal bersama" yang terus dilakukan dalam setiap produksi teater musikal bergaya opera produksi Teater Koma.

\section{Kepustakaan}

Antono, Untung Tri Budi. (2013). Pembentukan Struktur Tanda Latar Ruang, Waktu dan Suasana Lakon dari Naskah menjadi Tata Pentas Drama. Resital Jurnal Seni Pertunjukan, 14(2), 153-161.

Abercrombie, Nicholas, et all (ed). (2010). Kamus Sosiologi, Yogyakarta: Pustaka Pelajar.

Amstrong, David, et all (ed). (1972). Encyclopedia of World Drama, volumen 1 (A-D). New York: Mc Graw-Hill Book Company.

Baranello, M. (2016). Late Nineteenth-Century Opera and the Curse of the Effective. Cambridge Opera Journal, 28(3), 363-371. https://doi.org/http://dx.doi.org/10.1017/ S0954586716000422

Chaplin, C.P. 1989. Kamus lengkap Psikologi, Jakarta: CV Rajawali.

Cermatori, J. (2015). How to Make Sense of Music in the Theatre: A Primer for Beginners. Theatre Topics, 25(1), 67-76. Retrieved from https:// search.proquest.com/docview/1664818305? accountid $=38628$

Debord, Guy. (1994). The Society of The Spectacle. New York: Zone Books.

Griffin, EM (ed). (2006). A First Look At Communication Theory. New York: Mc Graw Hill.

Giordano, B. L., Egermann, H., \& Bresin, R. (2014). The Production and Perception of Emotionally Expressive Walking Sounds: Similarities between Musical Performance and
Everyday Motor Activity. PLoS One, 9(12). https://doi.org/http://dx.doi.org/10.1371/ journal.pone.0115587

Hall, E., Binney, W., \& Vieceli, J. (2016). Increasing loyalty in the arts by bundling consumer benefits. Arts Marketing, 6(2), 141-165. https://doi.org/http://dx.doi.org/10.1108/ AAM-01-2014-0008

Lütteken, L. (2009). NEGATING OPERA THROUGH OPERA: COSİ FAN TUTTE AND THE REVERSE OF THE ENLIGHTENMENT. Eighteenth-Century Music, 6(2), 229-241. https://doi.org/http:// dx.doi.org/10.1017/S1478570609990017

Meyer, S. C. (2008). Sound recording and the end of the Italian Lohengrin. Cambridge Opera Journal, 20(1), 1-24. https://doi.org/http:// dx.doi.org/10.1017/S0954586708002383

Müllensiefen, D., Gingras, B., Musil, J., \& Stewart, L. (2014). The Musicality of Non-Musicians: An Index for Assessing Musical Sophistication in the General Population. PLoS One, 9(2). https://doi.org/http://dx.doi.org/10.1371/ journal.pone.0089642

Petrini, K., Crabbe, F., Sheridan, C., \& Pollick, F. E. (2011). The Music of Your Emotions: Neural Substrates Involved in Detection of Emotional Correspondence between Auditory and Visual Music Actions. PLoS One, 6(4). https://doi.org/http://dx.doi.org/10.1371/ journal.pone.0019165

Posner, D. N. (2010). PERFORMANCE AS POLEMIC: TAIROV'S 1920 PRINCESS BRAMBILLA AT THE MOSCOW KAMERNY THEATRE. Theatre Survey, 51(1), 33-64. https://doi.org/http://dx.doi. org/10.1017/S0040557410000219

Rogers, V. L. (2014). John Gay, Ballad Opera and the Théâtres de la foire. Eighteenth-Century Music, 11(2), 173-213. https://doi.org/http:// dx.doi.org/10.1017/S1478570614000049

Riantiarno, N. 2017. Membaca Teater Koma (19772017). Jakarta: Yayasan Ko-Madjid (Koma) Foundation.

Ritzer, George, Douglas J Goodman. (2009). Teori Sosiologi. Yogyakarta: Kreasi Wacana.

Rustiyanti, Sri. (2014). Musik Internal dan 
Eksternal dalam Kesenian Randai. Resital Jurnal Seni Pertunjukan, 15 (2), 152-162.

Rustiyanti, Sri. 2013. Kompetensi Penari: Alua Patuik Raso Pareso. Reital Jurnal Seni Pertunjukan, 14(2), 153-161.

Suryajaya, Martin. 2016. Sejarah Estetika, Jakarta: Gang Kabel dan Indie Book Corner.

Seinen, N. (2009). Prokofiev's Semyon Kotko and the melodrama of High Stalinism. Cambridge Opera Journal, 21(3), 203-236. https://doi.org/http://dx.doi.org/10.1017/ S0954586710000212

Sheppard, W. A. (2009). Blurring the Boundaries: Tan Dun's Tinte and The First Emperor. The Journal of Musicology, 26(3), 285-326. https://doi.org/http://dx.doi.org/10.1525/ jm.2009.26.3.285

Teater Koma. (2013). Buku Acara pertunjukan musik teatrikal IBU produksi ke 131. Jakarta: Kerjasama Teater Koma dengan Djarum Apresiasi Budaya.

West, Richard, Lynn H. Turner. (2007). Introducing Comunication Theory: Analysis and Aplication. Boston: McGrawHill.

\section{Informan}

Ferosax (nama panggung) atau Fero Aldiansya Stefanus (nama asli) 29 tahun. Penata musik Teater Koma, Alumni Jurusan Seni Musik, Universitas Pelita Harapan. Bergabung dengan Teater Koma sejak tahun 2007 sampai sekarang. Fero juga sebagai Head Project of 9+ Project Indonesia:"Projecting Your Musical Idea."

Riantiarno, N., Adalah sutradara dan penuis naskah Teater Koma. Tinggal di Jakarta.

\section{Data Virtual}

http://anacarlya.blogspot.co.id/2013/09/prinsiphomofili-dan-heterofili-dalam.

http://audillacindy.blogspot.co.id/2014/12/judulpementasan-ibu-saduran-dari.html

https://www.teaterkoma.org/index.php/galeri-fotokoma

www. Slideshare.net, Juli 1, 2014. Opera: The art of emotion, Anndiva Mandley and Carol Williams. 